\title{
Determination of Fracture Mechanics Parameters Structural Components with Surface Crack Under Thermomechanical Loads
}

\author{
Katarina Maksimović ${ }^{1)}$ \\ Dragi Stamenkovic ${ }^{2)}$ \\ Mirko Maksimovic ${ }^{3)}$ \\ Ivana Vasović ${ }^{4)}$
}

\begin{abstract}
Rotational components of aero engine turbine are the most important components. It operates at high temperature and under conditions of extreme environmental attack such as oxidation, corrosion and wear. These conditions can cause cracking of rotational components. The failure damage modes of turbine are classified in terms of main components as flow path parts, rotating such as rotor, groove, disk, and blade. Aero-engine turbine components such as discs and blades are susceptible to environmentally assisted cracking. Unlike fatigue crack growth, this involves crack growth under constant load. If the crack grows long enough, sudden failure can occur with catastrophic consequences. It is therefore desirable to identify the limiting crack size within fixings so that they can be inspected at regular intervals and removed from service before failure occurs. Three dimensional axis-symmetric finite element models were created to simulate a disc and the portion of a blade. The finite element method (FEM) allowed the prediction of the point of crack initiation and the crack propagation using the orientations of the maximum principal stresses. Stress intensity factor (SIF) is the base parameter in strength analysis regarding fracture mechanics. For a correct determination of SIF in this paper, combining J-integral approach and FEM is used. $\mathrm{J}$-integral is a path independent integral around the crack tip.
\end{abstract}

Key words: aero engine, turbine, surface crack, fracture mechanics, thermomechanical load, finite element method.

\section{Introduction}

$\mathrm{D}$ URING the past four decades an extensive research of fracture mechanics has greatly enhanced the understanding of structural failure. Today, fracture mechanics is not only of academic interest, but plays an increasingly important role in structural design. New specifications have been established to meet the requirements of fracture mechanics, of airframes and power plant generation systems. Recently, a more stringent safety criterion, assuming a pre-existing flow in critical component, has been adopted to asses service life of aircraft. This emphasizes the significance of fracture mechanics as a tool for analysis.

The concept of linear elastic fracture mechanics which leads to the plane strain fracture toughness property, $\mathrm{K}_{\mathrm{IC}}$, has already been used in engineering applications $[1,2]$. The use of the J-integral and its critical value $\mathrm{J}_{\mathrm{C}}$ as a fracture criterion has also been developed into elasticplastic and fully plastic regimes [3, 4]. Various other approaches, such as resistance curve (R-curve) [5], crack tip displacement (CTOD) [5], and equivalent energy method [6] have been proposed but lack the flexible analytical basis of the J-integral procedure. Mechanical loading is not the only factor considered in design of the structure or structural components. Other possible situations may be caused by operational environments such as temperature, chemical reaction and irradiation have to be considered. In the operation of gas turbine engines, for example, thermal stresses can be as high as, or higher than, the centrifugal stresses. The worst condition of the combinations of thermal, centrifugal and gas bending stresses at elevated temperatures result in high local stresses which can lead to cracking of the turbine blades and rotor discs. Thus, thermal effects should not be ignored.

The effect of thermal gradients across a crack has also been the subject of analytical studies. Using the finite element method, Ayres [7, 15] illustrated the analytic procedure of evaluating surface cracks subjected to thermal shock. Emery, at al. $[8,16]$ demonstrated their singularity programming technique to consider the singular temperature field in calculation of the stress field. More recently, Ainsworth at al. $[9,17]$ and Wilson and $\mathrm{Yu}[10,18]$ investigated the use of modified J-integral to determine the crack tip stress intensity factors (SIF). For the fairly complicated geometry and loading conditions in the specimens of this study, the finite element technique is used to calculate both the temperature distribution and the stress intensity factor. A number of works have dealt with the crack problems.

The objective of the analytical work is to provide the relationship between the stress intensity factor and various mechanical and thermal load conditions. For a fairly complicated geometry and loading conditions in structural

\footnotetext{
1) City Administration of the City of Belgrade, Kraljice Marije 1, 11000 Belgrade, SERBIA

2) IDS GmbH Max-Planck-Ring 40 D-46049 Oberhausen, Germany - in SOUTH AFRICAN REPUBLIC

3) Belgrade Waterworks and Sewerage, Kneza Miloša 27, 11000 Belgrade, SERBIA

4) Institute GOŠA, Milana Rakića 35, 11000 Belgrade, SERBIA

Correspondence to: Katarina Maksimović; e-mail: katarina.maksimovic@beograd.gov.rs
} 
elements of this investigation, the finite element technique is used to calculate the temperature distribution and stress intensity factor.

\section{Fracture mechanical analysis of damaged structural components}

To analyze damaged turbine structural components it is necessary to determine stress intensity factors (SIFs) under thermo-mechanical loads. SIFs can be obtained using various analytical, numerical, and experimental methods.

The SIF is the only parameter used to determine the intensity of the stress field near the crack tip. There is a critical value for SIF called the (plane strain) fracture toughness, denoted as $\mathrm{K}_{\mathrm{IC}}$. When $\mathrm{K}_{\mathrm{I}}$ is smaller than $\mathrm{K}_{\mathrm{IC}}$, the crack does not grow. But, if $\mathrm{K}_{\mathrm{I}}$ is equal to $\mathrm{K}_{\mathrm{IC}}$, the crack starts to grow. The fracture criterion in linear elastic fracture mechanics is thus given by

$$
K_{I}=K_{I C}
$$

$K_{I C}$ indicates the maximum value of stress intensity factor at the crack tip that the material can bear, beyond that the crack will start to grow. Fracture toughness is a material property; it does not vary with a specimen's geometry or load applied.

Generally, the stress intensity factors are additive, provided that different loading conditions induce the same mode of crack extension. Hence, the fracture condition of the interaction of mechanical and thermal loads can be:

$$
\left(K_{I}\right)_{\text {mech. }}+\left(K_{I}\right)_{\text {thermal }}=\mathrm{K}_{\mathrm{I}}
$$

where $\left(K_{I}\right)_{\text {mech. }}$ is the stress intensity factor due to mechanical load and $\left(K_{I}\right)_{\text {thermal }}$ is the stress intensity factor due to temperature effect. In this study, a numerical investigation of temperature effect for different geometric aspects was considered. To analyze cracked structural components here ANSYS finite element software code [11] is used.

For the fairly complicated geometry and loading conditions the finite element technique is used to calculate the temperature distribution and the stress intensity factor. A number of works have dealt with crack problems [14-26, 30].

Once a finite element solution has been obtained, the values of the stress intensity factor can be extracted from it. Three approaches to the calculation of the stress intensity factors are currently used;

1. direct method,

2. indirect method and

3. J-integral method.

The direct method is based on the use of specialized crack-tip finite elements that contain $K_{I}$ and $K_{I I}$ directly as additional unknowns. This has been discussed by Benzley [10]. Benzley employed linear rectangular finite elements with supplementary singularity functions in the vicinity of crack tip. Barsoum [12] introduced a quarter/point isoparametric element to produce displacement proportional to the crack tip singularity function.

In the indirect method, the values of stress intensity factor are calculated using the nodal displacements in the element around the crack tip that is considered by Barsoum [12], Fig.1. Barsoum [12] also showed that a triangular quarter-point element, which is shown in Fig. 1, exhibits the $r^{1 / 2}$ singularity both on the boundary of the element and in the interior.

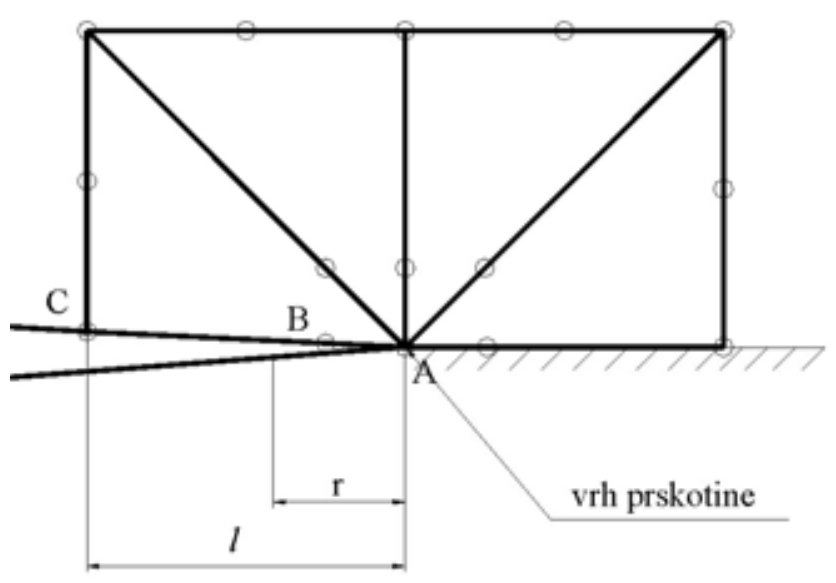

Figure 1. Four collapsed elements at crack tip

$$
\begin{aligned}
K_{I} & =\frac{2 \cdot \sqrt{2 \cdot \pi} \cdot G \cdot\left(4 \cdot v_{B}-v_{C}-3 \cdot v_{A}\right)}{(k+1) \cdot \sqrt{l}} \\
K_{I I} & =\frac{2 \cdot \sqrt{2 \cdot \pi} \cdot G \cdot\left(4 \cdot u_{B}-u_{C}-3 \cdot u_{A}\right)}{(k+1) \cdot \sqrt{l}}
\end{aligned}
$$

The third alternative is the so-called „J-integral“ approach. The path-independent J-line integral, which has been proposed by Rice [14], is defined as

$$
J=\int_{\Gamma}\left(W d x_{2}-T_{i} \frac{\partial u_{i}}{\partial x_{1}} d s\right)
$$

where $W$ is the elastic strain energy density, $\Gamma$ is any contour about the crack tip shown in Fig. $1 \mathrm{a}, T_{i}$ and $u_{i}$ are the traction and displacement components along the contour and $s$ is arch-length along the contour, $x_{1}$ and $x_{2}$ are the local coordinates such that $x_{1}$ is along the crack.

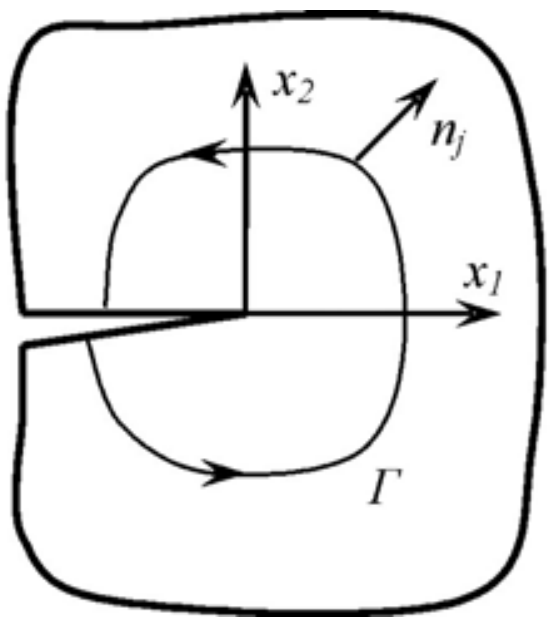

Figure 1a. Arbitrary contour and coordinate configuration

The J-integral is path dependent for cases which iclude thermal stress terms. To include thermal stress terms in this work the modified integral $J^{*}[13]$ is used in the next form:

$$
\begin{gathered}
J^{*}=\int_{\Gamma}\left(W^{*} d x_{2}-\sigma_{i j} \frac{\partial u_{i}}{\partial x_{1}} n_{j} d S\right)+\frac{E a}{1-2 v} \int \varepsilon_{i i} \frac{\partial \theta}{\partial x_{1}} d A \\
W^{*}=W-\frac{E \alpha \theta}{2(1-2 v)} e_{i i}
\end{gathered}
$$




$$
\begin{gathered}
\sigma_{i j}=\lambda \varepsilon_{i i} \delta_{i j}+2 \mu \varepsilon_{i j}-\frac{E \alpha}{1-2 v} \theta \delta_{i j} \\
W=\frac{1}{2} \sigma_{i j} \varepsilon_{i j}
\end{gathered}
$$

where $\mu$ and $\lambda$ Lame's constants, $\theta$ is the temperature and $\alpha$ is the coefficient of thermal expansion. If only the mode I loading is considered, then equation (2.3) for the plane stress condition reduces to:

$$
J^{*}=\left(1-v^{2}\right) K_{I}^{2} / E
$$

The values of $K_{I}$ for various thermo-mechanical problems were calculated, according to equations (2.1) and (2.7), and are presented in numerical validation. In this work the J-integral approach has been selected for determination stress intensity factors of plates with surface crack under thermo-mechanical loads. The finite element method offers two advantages in the numerical evaluation of the J-integral: (1) No specialized idealization is required near the crack tip, (2) A coarse mesh can be used to achieve an accurate solution. The J-integral is path dependent for cases which include residual, inertial or thermal stress terms or loading along the crack face.

\section{Numerical validation}

The subject of this analysis is the impact of changes in thermal load to the value of the stress intensity factors. In Fig.1, the plate with surface semi-elliptical crack subjected to thermal load is shown. Ratio of length plate, $h$, and plate width, $b$, remains constant with respect to the depth of the crack, a, and crack length, c, so that we can consider that the obtained values of the stress intensity factor, $K_{I}$, are closed to those in infinite plate. In the analysis of plates with semi-elliptical surface crack subjected to thermal load, crack geometry will be used as follows: $a / c=1 / 3, a / c=1$ and $a / c=2$ and the crack depth $a / t=0.2$. In Fig.2, the geometry of the crack load to change the temperature field under the influence of thermal load is shown. The material we used in the analysis is Rene - 41 (DIN 2.4973) which is commonly used for manufacturing casing of jet engine. The thermo-mechanical properties are given in Table 1 .

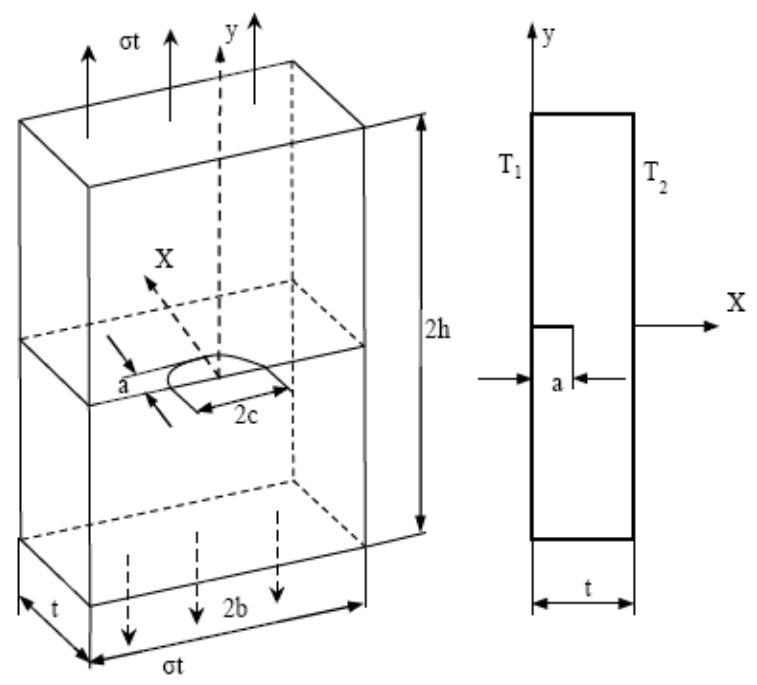

Figure 2. Geometry properties of the plate under thermal load
Table 1. Thermomechanical material properties

\begin{tabular}{||c|c|c|c|c||}
\hline Material & $\begin{array}{c}\text { Young } \\
\text { modulus } \\
(\mathrm{GPa})\end{array}$ & $\begin{array}{c}\text { Poisson } \\
\text { coefficient }\end{array}$ & $\begin{array}{c}\text { Coefficient of } \\
\text { thermal expansion } \\
\left(10-5 /{ }^{\circ} \mathrm{C}\right)\end{array}$ & $\begin{array}{c}\text { Thermal conduc-| } \\
\text { tivity } \\
\left(\mathrm{W} / \mathrm{m}^{\circ} \mathrm{C}\right)\end{array}$ \\
\hline \hline Rene-41 & 219,7 & 0,25 & 1,67 & 11,5 \\
\hline
\end{tabular}

In the analysis it was assumed that the characteristics of the material are constant and independent of temperature. The thermal analysis of the plate was observed following the thermal load on the surface of the plate: $T_{1}=5 T_{2}, T_{1}=$ $10 T_{2}$ and $20 T_{2}$, where $T_{1}=T(\mathrm{x}=0)$ and $T_{2}=T(x=t)=T_{0}$. The geometry of surface cracks was observed for three cases: $a / c=1 / 3, \mathrm{a} / c=1$ and $\mathrm{a} / c=2$ with the same crack depth $\mathrm{a} / t=0.2$.

The general equation for calculating the stress intensity factor, mode I, for surface semi-elliptical crack is given by the following expression [27]:

$$
K_{l}=S \sqrt{\pi \frac{a}{Q}} F\left(\frac{a}{t}, \frac{a}{c}, \frac{c}{b}, \phi\right)
$$

where for the case of thermal loading and plane strain $S=\alpha_{1} \mathrm{ET}_{\mathrm{O}} /(1-v)$, while for the case of plane stress state $S=\alpha_{1} \mathrm{ET}_{\mathrm{O}}$ (Erdogan and $\mathrm{Wu}, 1996$ [28]). Shape factor, $Q$, is the square of elliptic integrals of the second order, which is equal to half compared to arc length and the length of the ellipse major axis (Merkle, 1973 [29]). The values of the shape factors can be approximated by the following expression:

$$
Q=\left\{\begin{array}{l}
1+1,464\left(\frac{a}{c}\right)^{1,65} \text { za } a / c \leq 1 \\
1+1,464\left(\frac{c}{a}\right)^{1,65} \text { za } a / c>1
\end{array}\right.
$$

The function $F$ in equation (3.1) includes the effect of plate dimensions, geometry and position cracks along the crack front. In the further analysis we introduce a normalized stress intensity factor, which is represented by the following expression:

$$
K_{I N}=\frac{K_{I}}{S \sqrt{\frac{\pi \alpha}{Q}}}=F\left(\frac{a}{t}, \frac{a}{c}, \frac{c}{b}, \phi\right)
$$

The introduction of normalized stress intensity factor, "Shape factor" allows us to include in the analysis: the geometry, material properties and loads.

To determine the stress intensity factor, mesh with finite elements is used which is shown in Fig.3. In this analysis ANSYS finite element software code [11] is used. For the finite element mesh elements with twenty nodes were used. As the field of stresses and displacements around the crack tip singular, to carry out a correct analysis made use of singular finite elements. In the radial direction around the crack tip was modeled as three rings of finite elements, while along the crack front used sixteen finite elements, $\varphi=$ $0-\pi / 2$. 


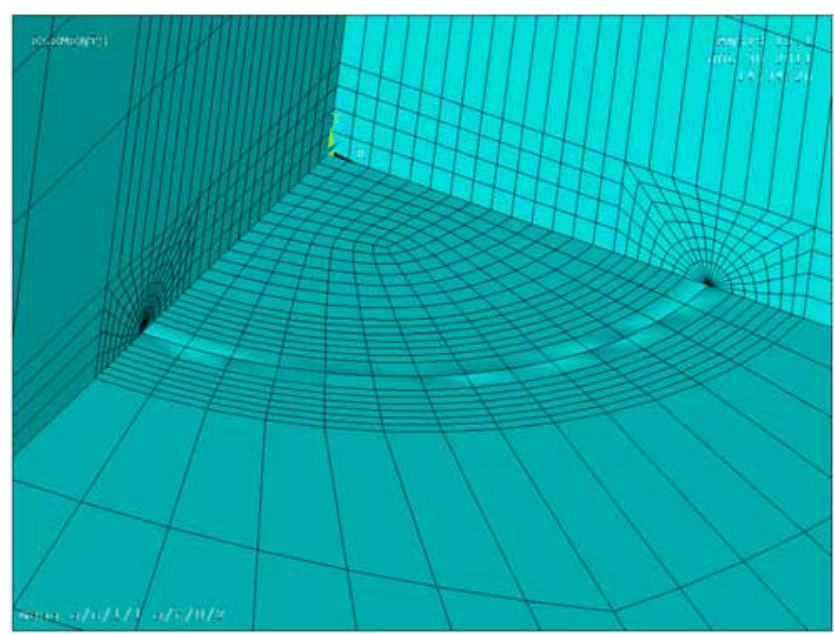

Figure 3. Mesh of finite elements for plate with surface crack, $a / c=1$ and $a / t=0.2$

\section{The stress intensity factors under thermal loads}

This paper analyzes the plate with surface crack under the influence of different thermal load. Plate geometry and boundary conditions are shown in Fig.2. The material properties of the thermo-mechanical analysis are given in Table 1, with the constant material properties in relation to temperature. In the analysis, the thermal load acting on the side panel of a surface crack. Distribution of temperature field along the crack tip is shown in Fig.4.

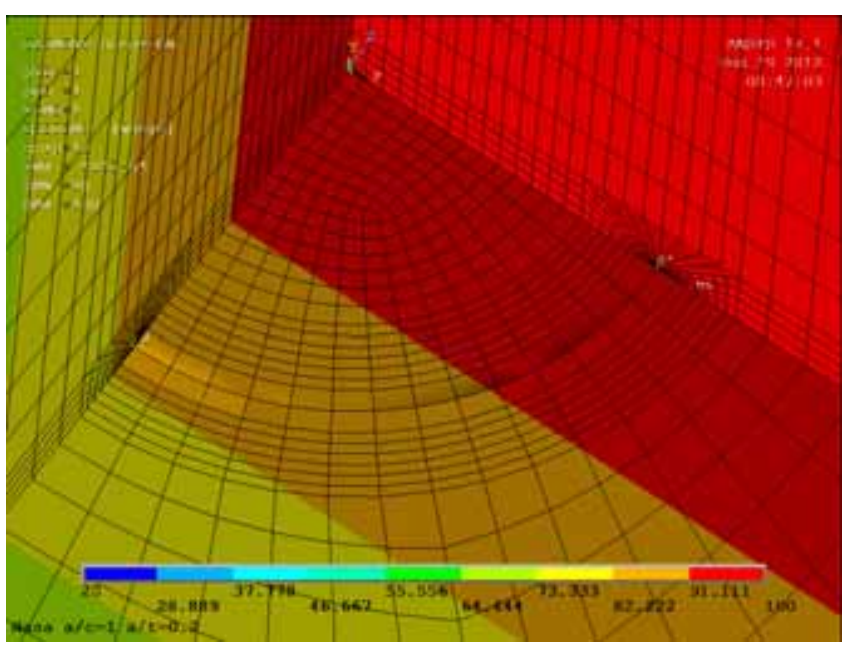

Figure 4. Temperature field along crack front

Figures 5-7 show the normalized stress intensity factor under the influence of different thermal load for the following geometry of the crack $\mathrm{a} / \mathrm{c}=1 / 3, \mathrm{a} / \mathrm{c}=1$ and $\mathrm{a} / \mathrm{c}=2$ and a constant ratio of crack depth and plate thickness $\mathrm{a} / \mathrm{t}=$ 0.2. In Fig. 1 the temperature gradient plate is shown, where the temperature $T_{1}$ at the surface with crack 5, 10 and 20 times higher compared to the surface without cracks $T_{2}$. Following the thermal analysis of the normalized stress intensity factors for different crack geometries are given in Table 2. Normalized $K_{I N}$ were calculated based on the thermal load by using the Equation 3.4:

$$
K_{I N}=\frac{K_{I}}{E \alpha T \sqrt{\pi \alpha}}
$$

As the ratio a/c increases from $1 / 3$ to 1 , the values of normalized stress intensity factor at the surface of the plate with crack, $\phi=0$, decreases and with the further increasing of $a / \mathrm{c}$ from 1 to 2 , increases the value of $\mathrm{K}_{\mathrm{IN}}$. Also the value of $\mathrm{K}_{\mathrm{IN}}$ in the deepest point of crack, $2 \phi / \pi=1$, monotonically decreases with increasing of a/c, and $T_{1} / T_{2}$.

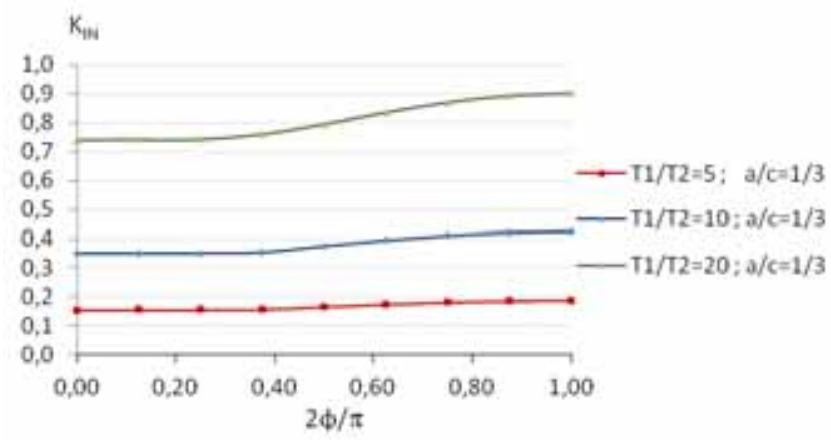

Figure 5. $K_{I N}$ for the plate under thermal load and crack geometry, $a / c=1 / 3$ and $a / t=0.2$

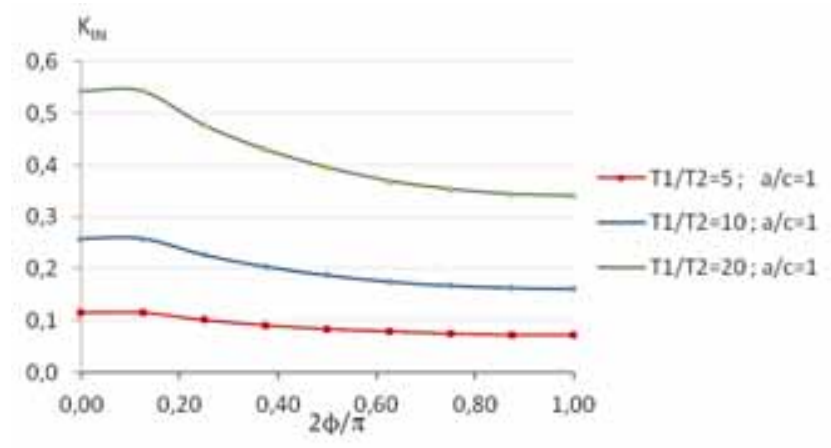

Figure 6. $K_{I N}$ for the plate under thermal load and crack geometry, $a / c=1$ and $a / t=0.2$

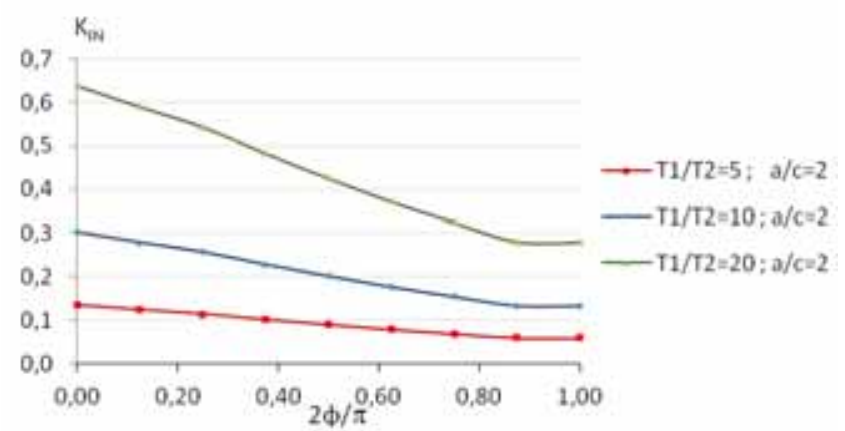

Figure 7. $K_{I N}$ for the plate under thermal load and crack geometry, $a / c=2$ and $a / t=0.2$

Table 2. Normalized values $K_{I N}$ for the plate under thermal load

\begin{tabular}{|c|c|c|c|c|}
\hline \multirow{4}{*}{$a / t$} & \multirow{4}{*}{$2 \varphi / \pi$} & \multicolumn{3}{|c|}{ Thermal load } \\
\hline & & \multicolumn{3}{|c|}{$a / c=1 / 3$} \\
\hline & & \multicolumn{3}{|c|}{$T_{1} / T_{2}$} \\
\hline & & 5 & 10 & 20 \\
\hline \multirow{12}{*}{0.2} & 0.000 & 0.1557 & 0.3502 & 0.7394 \\
\hline & 0.125 & 0.1563 & 0.3508 & 0.7400 \\
\hline & 0.250 & 0.1569 & 0.3515 & 0.7406 \\
\hline & 0.375 & 0.1576 & 0.3546 & 0.7587 \\
\hline & 0.500 & 0.1670 & 0.3757 & 0.7931 \\
\hline & 0.625 & 0.1756 & 0.3951 & 0.8341 \\
\hline & 0.750 & 0.1828 & 0.4112 & 0.8681 \\
\hline & 0.875 & 0.1876 & 0.4220 & 0.8909 \\
\hline & 1.000 & 0.1892 & 0.4258 & 0.8989 \\
\hline & & \multicolumn{3}{|c|}{$a / c=1$} \\
\hline & & \multicolumn{3}{|c|}{$T_{1} / T_{2}$} \\
\hline & & 5 & 10 & 20 \\
\hline & 0.000 & 0.1145 & 0.2576 & 0.5438 \\
\hline & 0.125 & 0.1145 & 0.2576 & 0.5438 \\
\hline & 0.250 & 0.1006 & 0.2263 & 0.4778 \\
\hline 0.2 & 0.375 & 0.0906 & 0.2039 & 0.4306 \\
\hline
\end{tabular}




\begin{tabular}{||l|l|c|c|c||}
\hline \multirow{6}{*}{} & 0.500 & 0.0833 & 0.1875 & 0.3957 \\
& 0.625 & 0.0790 & 0.1753 & 0.3698 \\
& 0.750 & 0.0745 & 0.1676 & 0.3538 \\
& 0.875 & 0.0724 & 0.1630 & 0.3440 \\
& 1.000 & 0.0717 & 0.1614 & 0.3408 \\
\hline \multirow{3}{*}{0.2} & & \multicolumn{3}{|c||}{$a / c=2$} \\
\cline { 3 - 5 } & & $T_{1} / T_{2}$ \\
\cline { 3 - 5 } & & 5 & 10 & 20 \\
\hline & 0.000 & 0.1342 & 0.3019 & 0.6373 \\
& 0.125 & 0.1239 & 0.2788 & 0.5887 \\
& 0.250 & 0.1142 & 0.2569 & 0.5424 \\
& 0.575 & 0.1015 & 0.2283 & 0.4816 \\
& 0.625 & 0.0894 & 0.2011 & 0.4245 \\
& 0.750 & 0.0783 & 0.1761 & 0.3716 \\
& 0.875 & 0.0684 & 0.1539 & 0.3248 \\
& 1.000 & 0.0591 & 0.1330 & 0.2807 \\
\hline
\end{tabular}

\section{Conclusions}

In this work, the computation procedure is performed to determine the stress intensity factors for structures with surface crack under the influence of thermal loads. Detailed analysis was carried out at plate with different surface crack geometries length $(\mathrm{a} / \mathrm{c})$ and constant ratio of plate $(\mathrm{a} / \mathrm{t}=0.2)$ and different thermal loads. In the analysis it was assumed that the material is isotropic and that the material properties are independent of temperature. Based on the given loads, boundary conditions and plate geometry, the calculated values of the stress intensity factors just described the mode I. The obtained values of the stress intensity factors are presented in a standard normalized form, tabular and graphical form. The conducted analysis shows the complexity of the behavior of surface cracks and its influence on the resistance of the structure during the process of exploitation.

A description of a model which is developed to examine the thermal effect on fracture was presented. Interaction of mechanical and thermal effects was correlated in terms of $\mathrm{K}_{\mathrm{IC}}$. The values of the stress intensity factors were calculated by use the J-integral and displacement method.

The stress intensity factor (SIF) for an embedded elliptical crack in a turbine rotor under thermal and centrifugal loading, for a semi-elliptical surface crack in a finite plate are determined by means of finite elements and J-integral method.

\section{Acknowledgements}

Parts of this research were supported by the Ministry of Science, Education and Technological Development of the Republic of Serbia through the Mathematical Institute SANU Belgrade (grant number OI 174001: Dynamics of hybrid systems with complex structures. Mechanics of materials), and the Project grant number TR 35011: Integrity of equipment under combined fatigue and thermal loads.

\section{References}

[1] WESSEL,E.T., CLARK,W.G., WILSON,W.K.: Engineering methods for the design and selection of materials against fracture, U.S. Army Tank and Automative Center Rep., Contract No. Da/30/069/AMC 602 (T), 1966.

[2] KIM,Y-J, SHIM,D-J, CHOI,J-B, KIM,Y-J: Approximate J estimates for tension-loaded plates with semi-elliptical surface cracks. Eng. Fract. Mech., 2002, 69, pp.1447-1463.

[3] MAKSIMOVIĆ,K., NIKOLIĆ.S.V., MAKSIMOVIĆ,S.: Modeling of the Surface Cracks and Fatigue Life Estimation, ECF 16, 16 ${ }^{\text {th }}$ European Conference of Fracture, Alexandroupolis, GREECE, 2006.
[4] TADA,H, PARIS,P.C., IRWIN,G.R.: The stress analysis of cracks handbook, $3^{\text {rd }}$ Edition, ASME/IMechE, 2000.

[5] Begley,J.A, LANDES,J.D.: in Progress in Flow and Fractures Toughness Testing, ASTM STP 536, American Society for Testing and Materials, 1973, pp.243-262.

[6] AYRES,D.J.: Three-dimensional elastic analysis of semi-elliptical surface cracks subject to thermal shock, computation fracture mechanics, Rybecki, E.F and Benzley, S.E., eds., ASME, 1975, pp.133-143.

[7] EMERY,A.F., NEIGHBORS,P.K. KOBAYASHI,A.S., LOVE,W.J.: Stress intensity factors in edge-cracked plates subjected to transient thermal singularities, Journal of Pressure Vessel Technology, Trans., ASME, February 1977, p.100.

[8] AINSWORTH,R.A., NEALE,B.K., PRICE,R.H.: Fracture behavior in the presence of thermal strains, Proceedings of the International Mechanical Engineering Conference on Tolerance of Flow in Pressurized Components, London, May 1978, p.197.

[9] WILSON,W.K., YU,I.W.: The Use of the J-integral in thermal stress crack problems, Int Journal of Fracture, August 1979, Vol.15, No.4, pp.317-387.

[10] BENZELEY,S.E.: Representation of singularities with isoparametric finite elements, Int. J. Numerical Methods in Engineering, 1974, Vol.8, p.537.

[11] ANSYS Release 17, Finite Element software code, 2016.

[12] BARSOUM,R.S.: On the use of isoparametric finite elements in linear fracture mechanics, Int. J. Numerical Methods in Engineering, 1976, Vol.10, pp.25-37.

[13] WILSON,W.K., YU,I.W.: The use of the J-integral in thermal stress crack problems, Int. J. Fracture, August 1979, Vol.15, No.4, pp.317-387.

[14] STAMENKOVIC,D.: Determination of fracture mechanics parameters using FEM and J-integral approach, Finite element simulation of the high risk constructions, Special Session, within $2^{\text {nd }}$ WSEAS International Conference on Applied and Theoretical Mechanics (MECHANICS'06), Eds Mijuca, D and Maksimovic, S., Venice, ITALY, 2006.

[15] MAKSIMOVIĆ,S.: Finite Elements in thermoelastic and elasticplastic fracture mechanics, Proceedings of The $3^{\text {th }}$ International Conference held University held at College, Swansea, $26^{\text {th }}-30^{\text {th }}$ March 1984, pp.495-504.

[16] MAKSIMOVIC,S., POSAVLJAK,S., MAKSIMOVIC,K., NIKOLIC,V., DJURKOVIC,V.: Total fatigue life estimation of notched structural components using low-cycle fatigue properties, Journal Strain, 2011, 47 (suppl.2), pp. 341-349.

[17] NEWMAN JR,J.C., RAJU,I.S.: An empirical stress intensity factor equation for the surface crack, Engng. Fract. Mechanics, 1981, 15, pp. 185-192.

[18] HOSSEINI,A., MAHMOUD,M.A.: Evaluation of stress intensity factor and fatigue growth of surface cracks in tension plates, Engineering Fracture Mechanics, 1985, Vol.22, No.6, pp.957-974.

[19] LIN,H.B., SMITH,R.A.: Shape growth simulation of surface crack in tension fatigue round bars, Int. J. Fatigue, 1997, 19, pp.99-109.

[20] BOLJANOVIĆ,S., MAKSIMOVIĆ,S., DJURIĆ,M.: Fatigue strength assessment of initial semi-elliptical cracks located at a hole, International Journal of Fatigue, 2016, 92, pp. 548-556.

[21] SCOTT,P.M., THORPE,T.W.: A critical review of crack tip stress intensity factors for semi-elliptic crack, Fatigue of Engineering Materials and Structures, 1981, Vol.4 No.4, pp.291-309.

[22] MCGOWAN,J.E.: A critical evaluation of numerical solutions to the benchmark surface flaw problem, Experimental Mechanics, 1980, Vol.20, No.8, pp.253-264.

[23] MAKSIMOVIĆ,K., STAMENKOVIĆ,D., MILOVIĆ,Lj.: Influence of Surface Crack Shape on Crack Growth Rate in Plate, Proc. $4^{\text {th }}$ Int. Congress of Serbian Society of Mechanics, 4-7. June, 2013, Vrnjačka Banja, SERBIA.

[24] SMITH,C.W., PETERS,W.H., KIRBY,G.C., ADONIAN,A.: Fracture Mechanics, ASTM STP 743, American Society for Testing and Materials, 1981, pp.422-437.

[25] CATER,D.K., CANDA,W.R., BLIND,J.A.: Experimental evaluation of stress-intensity solutions for surface flaw growth in plates, Surface-Crack Growth: Models, Experiments, and Structures, ASTM STP 1060, 1990, pp.215-236.

[26] YAGAWA,G., KITAJIMA,Y.: Three-dimensional fully plastic solutions for semi-elliptical surface cracks, Int. J. Pressure Vessels and Piping, 1993, 53, pp.457-510. 
[27] NEWMAN JR,J.C., RAJU,I.S.: An empirical stress intensity factor equation for the surface crack, Engineering Fracture Mechanics, 1981, Vol.15, No.1, pp.185-192.

[28] ERDOGAN,F., WU,B.H.: Crack problem in functionally graded material layers under thermal stresses, Journal of Thermal Stresses, 1996, Vol.19, pp.237-265.

[29] MERKLE,J.G.: A Review of some of the existing stress-intensity factor solutions for part-through surface crack, ONRL-TM-3983, Oak Ridge, TN, Jan 1973.
[30] MAKSIMOVIĆ,K., JANKOVIĆ,M., BERIĆ,N., NIKOLIĆSTANOJEVIĆ,V: Numerical analysis of damaged stiffened panels with respects of fracture mechanics, Scientific Technical Review, ISSN 1820-0206, 2014, Vol.64, No.1, pp.30-34.

\title{
Određivanje parametara mehanike loma elemenata konstrukcija sa površinskom prskotinom pod dejstvom termomehaničkih opterećenja
}

\begin{abstract}
Elementi konstrukcija, poput turbine avionskih motora, predstavljaju važne noseće strukturalne elemente. Oni rade na visokim temperaturama i složenim ambijentnim uslovima takvim kao što su oksidacija, korozija i vlaga. Ovi uslovi mogu dovesti do loma rotacionih komponenti. Postoji više oblika lomova kod turbine koji se u osnovi vezuju za njene glavne komponente poput samog rotora, diska ili lopatica. Sami diskovi i lopatice kod turbine avionskih motora su podložne ambijentnim uslovima koji podpomažu inicijalnim oštećenjima. Ako neotkrivena prskotina postoji duži vremenski period tokom eksploatacije ona se može proširiti preko kritične vrednosti i dovesti do efektivnog loma. Stoga je bitno da se definiše kritična vrednost dužine prskotine i da se ista kontroliše tokom redovnih servisnih pregleda kako bi se izbegli katastrofalni lomovi. Trodimenzioni modeli konačnih elemenata (MKE), uključivši i specijalne singularne konačne elemente, su u radu korišćeni da modeliraju disk na delu sa vezivanjem lopatice. Primenom MKE može se precizno odrediti kritična zona sa aspekta pojave inicijalnih prskotina a potom i proces njenog širenja. Faktor intenziteta napona (FIN) je osnovni parametar za analizu čvrstoće sa aspekta mehanike loma. Za korektno određivanje FIN u radu je korišćen J-integral metod u sprezi sa MKE uključivši specijalne singularne konačne elemente oko vrha prskotine. Osnovna prednost J-integral metode je u tome što je isti nezavisan od putanje oko vrha prskotine.
\end{abstract}

Ključne reči: avionski motor, turbina, površinska prskotina, mehanika loma, termomehaničko opterećenje, metoda konačnih elemenata.

\section{Определение показателей механики разрушения деформируемого твёрдого тела структурных компонентов с поверхностной трещиной под действием термомеханических нагрузок}

\begin{abstract}
Такие элементы конструкции, как турбина авиационных двигателей, являются важными несущими элементами конструкции. Они работают при высоких температурах и в сложных условиях окружающей среды, таких как окисление, коррозия и влага. Во время работы турбины, высокие напряжения приводят к появлению дефектов типа начальных трещин и даже их расширения. Эти условия могут привести к разрушению вращающихся компонентов. Есть несколько форм разрушения турбины, которые в основном связаны с её основными компонентами, такими, как сам ротор, диск или лопатки. Сами диски и лопатки турбин в авиационных двигателях подвергаются условиям окружающей среды, которые вызывают первоначальный ущерб. Если нераскрытая трещина существует более длительный период времени во время работы она может быть расширена за пределы критического значения и привести к эффективному разрушению. Поэтому крайне важно, определить критическое значение длины трещины и контролировать её во время регулярного обзора услуг для того, чтобы избежать катастрофических разрушений. Трёхмерные модели конечных элементов (МКЭ), в том числе и специальных особых единичных конечных элементов, в работе использованы для моделирования диска в части связывания лопатки. По методу конечных элементов могут быть точно определены критические зоны с точки зрения появления начальной трещины, и затем и процесс её расширения. Коэффициент интенсивности напряжений (КИН) является основным параметром для анализа прочности с точки зрения механики разрушения. Для правильного определения КИН в работе использован эквивалентный Ј-интегральный метод в сочетании с МКЭ, в том числе и специальные особые конечные элементы вокруг кончика трещины. Главное преимущество Ј-интегрального метода является в том, что он не зависит от пути вокруг кончика трещины.
\end{abstract}

Ключевые слова: авиационный двигатель, турбина, поверхностная трещина, механика разрушения, термомеханическая нагрузка, метод конечных элементов. 


\title{
Détermination des paramètres de la mécanique de fracture des éléments de constructions à la fissure superficielle sous l'action des charges thermomécaniques
}

\begin{abstract}
Les éléments de constructions telle turbine des moteurs d'avion sont les éléments structuraux importants. Ils fonctionnent à hautes températures et dans les conditions complexes d'ambiance comme oxydation, corrosion et humidité. Au cours de l'exploitation de la turbine à cause de hautes tensions se produisent les endommagements initiaux telles les fissures qui grandissent. Ces conditions peuvent causer la fracture des composantes rotatives. Il existe plusieurs formes de fracture chez la turbine liées à ces composantes principales - rotor, disque ou aubes. Les disques et les aubes chez la turbine du moteur d'avion sont sensibles aux conditions d'ambiance qui favorisent les endommagements initiaux. Si la fissure non découverte existe longtemps pendant l'exploitation elle peut croître au-delà de la valeur critique et causer la fracture effective. Pour cela il est essentiel de définir la valeur critique de la longueur de fissure et de la contrôler pendant l'examen de service régulier pour éviter les fractures catastrophiques. Les modèles des éléments finis à trois dimensions y compris les éléments finis spéciaux et singuliers on été utilisés pour modeler le disque sur la portion de l'aube avec liage. Par la méthode des éléments finis il est possible de déterminer la zone critique sous l'aspect de l'apparition des fissures initiales ainsi que le processus de la croissance. Le facteur de l'intensité de charge (FIC) est le paramètre basique pour les analyses de la résistance sous l'aspect de la mécanique de fracture. Pour la détermination correcte de FIC on a appliqué la méthode $\mathbf{J}$ - intégral avec la méthode des éléments finis y compris les éléments singuliers finis et spécifiques autour du sommet de la fissure. L'avantage principale de la méthode $\mathbf{J}$ - intégral est son indépendance de la trajectoire autour du sommet de la fissure.
\end{abstract}

Mots clés: moteur d'avion, turbine, fissure superficielle, mécanique de fracture, charge thermodynamique, méthode des éléments finis. 